\title{
SOCIAL MEDIA AND EFFORT TO COAX YOUNG VOTERS IN JAKARTA, INDONESIA
}

\author{
Prida Ariani Ambar Astuti ${ }^{1^{*}}$ and P. Hangsing ${ }^{2}$ \\ ${ }^{1}$ Research Scholar at Library and Information Science Department \\ North-Eastern Hill University, Shillong, Meghalaya, 793022, INDIA \\ Email: pridaariani@gmail.com \\ ${ }^{2}$ Assistant Professor at Library and Information Science Department \\ North-Eastern Hill University, Shillong, Meghalaya, 793022, INDIA \\ Email: roel.hangsing@gmail.com \\ * Corresponding author
}

\begin{abstract}
Political information is often regarded as a topic that is too heavy and not appealing to young voters and this makes them become apathetic. They also considered that there was no point in participating in politics because whatever they do can not change the situation. However, these conditions change with the emergence of social media. Social Media is a new media, which have different characteristics from previous media. It also has the potential to maximize the interactivity and two-way communication that allows users to engage and participate actively. However, with the presence and advantages of social media, can this media change the interest of young voters to political information, which in turn encourages them to participate in the election? By using a survey of students in departments that are accredited ' $\mathrm{A}$ ' in Jakarta, the research concluded that the ability to convey information, the opportunity to connect directly with the candidate, as well as the opportunity to actively participate contained in social media, had an impact on the level of interest in political information and decision-making to select a candidate for young voters in elections.
\end{abstract}

Keywords: Social media, political information, election, young voter, political participation.

\begin{abstract}
ABSTRAK
Informasi politik seringkali dianggap sebagai sebuah topik yang terlalu berat dan tidak menarik bagi pemilih muda sehingga hal ini menyebabkan mereka menjadi apatis. Mereka juga menganggap bahwa tidak ada gunanya berpartisipasi dalam politik karena apapun yang mereka lakukan tidak dapat mengubah keadaan. Namun kondisi ini berubah seiring dengan kehadiran media sosial. Media sosial merupakan media baru dengan karakteristik yang berbeda dengan media sebelumnya serta memiliki potensi untuk memaksimalkan interaktivitas dan komunikasi dua arah sehingga memungkinkan penggunanya untuk terlibat dan berpartisipasi langsung. Namun dengan kehadiran dan kelebihan yang dimiliki media sosial, mampukah media ini mengubah ketertarikan pemilih muda terhadap informasi politik yang pada akhirnya mendorong mereka untuk berpartisipasi dalam pemilu? Dengan menggunakan metode survei yang dilakukan terhadap mahasiswa jurusan yang terakreditasi 'A' di Jakarta, riset ini menyimpulkan bahwa kemampuan untuk menyampaikan informasi, adanya kesempatan untuk terhubung langsung dengan kandidat serta adanya peluang untuk aktif berpartisipasi yang terdapat dalam media sosial, membawa pengaruh terhadap tingkat ketertarikan akan informasi politik dan pengambilan keputusan untuk memilih salah seorang kandidat bagi pemilih muda dalam pemilu.
\end{abstract}

Kata kunci: Media sosial, informasi politik, pemilu, pemilih muda, partisipasi politik.

\section{INTRODUCTION}

In our everyday lives, the media keeps on informing us through exposure to the thousands of choices with unveiled attempts to seduce us into these choices. The whole point of communicating information is to have an effect. The wide opportunities of exposure to information communication continually influence how we think, react, and respond. Media can influence how users think and evaluate about something.
Through the media, users gain the knowledge and understanding to shape their perceptions.

Since its presence in the 1997, social media have become coordinating tools for nearly all of the world's political movements. Facebook and other social networking site have been used to mobilize individuals to participate in protests around the globe such as the impeachment trial of Philippine President Joseph Estrada in January 17, 2001 and the London 
youth riots in the summer 2011. Furthermore, in 2009 Iranian protest against the reelection of Mahmoud Ahmadinejad and most especially a series of antigovernment uprisings in North Africa and the Middle East, starting from Tunisia in December 2010 (Carlisle and Patton, 2013). Former Philippine president, Joseph Estrada blamed 'the text messaging generation' for his downfall. Social networking sites, in particular, played a crucial role in the 2011 Egyptian revolution, prompting an activist to say, "We use Facebook to schedule the protest, Twitter to coordinate, and YouTube to tell the world" (Gong, 2011).

Social media is certainly an instrument, which allows the direct provision of information and engagement. Social media allows people to interact with others without having to meet. Social media changed the monolog model in traditional media, which is one-tomany to be dialogic model of many-to-many communication. The defining aspects of the social media are that they are social, digital, multimedia, interactive, asynchronous, and narrowcast. As digital media, social media are forms of media content that combine and integrate data, text, sound, and images of all kinds; are stored in digital formats, and are increasingly distributed through networks. Social networking can help foster a sense of interpersonal trust and cooperation among individuals in informal social networks that could potentially encourage civic engagement in politics and democracy (Carlisle and Patton, 2013). With its many advantages, it is not surprising that social media is able to get people to engage, participate or perform an action.

In many countries, the internet is a crucial aspect of election campaigns and is growing more important. Advances in technology can enable a restructuring of the political system. Political actors can now use internet to supply the original message that they want to present to citizens. With a unique combination of textual, auditory, and visual components, new technologies show the potential to present political and civic material to citizens. Messages distributed by internet have the potential to reach very large and plural audiences anonymously. The messages conveyed can be utilized to inform convince and influence people. The relevant political message must be submitted to the voters as a weapon attempting to win an election. In social media, the relationship between the message and the voters is directly mediated without filter; even debate with the opposition can be done through social media to provide an impartial and relevant overview of the policy about constituents.

Young people are often viewed, as most groups do not care, as apathetic towards politics. Social media platform have paved the way for the reconceptualization of political engagement, especially among the youth. Youth see that engagement in participatory politics by doing activities such as status updates, tweets, share, post comments, etc. are ways to get involved in politics. Internet reduces the barriers to participation and thus reduces social inequality that exists in public life. In addition, the factors of political knowledge, political experience, years of education, level of interest in politics, and strength of partisanship also became a driving factor of someone participating in politics (Dalager, 1996). This statement is also in line with behavioral theories of political participation which state that the social and economic characteristics of voters, education, and income are the most important variable in explaining whether one votes (Tolbert and McNeal, 2003). A well-educated population somehow stimulated to be interested in political matters. Increased media exposure of the candidates and greater personal contact with the voters can also increase the voters' knowledge of political information.

This study will use the Jakarta Governor Election 2012 as the research context. Jakarta Governor Election 2012 was interesting to watch. Not because of the racial issues but the new model campaigning was creative and innovative with the help of communication technology such as social media. Jakarta Governor Election 2012 was the first election in Indonesia that utilize the social media in political campaigns. In previous years, the election campaign was done with banners, billboards or posters having images of the candidates everywhere or mobilization of the mass through convoys of motorcycles. However, in Jakarta Governor Election 2012, social media is used as the main medium of campaign.

More creative and unusual ways of campaigning was used by Jokowi-Ahok then their rivals, Foke-Nara. In the campaign, Jokowi-Ahok took vantages of the social media to reach out to the young voters. They employed social media such as Facebook and Twitter, which at that time was the most used social media in Indonesia (Kompas.com, 2012). Besides Facebook and Twitter, Jokowi-Ahok also use an online game called "Selamatkan Jakarta" (Save Jakarta). Campaign on the internet can also be seen from the visualization adaptation "What makes you beautiful", a song of the international fame, One Direction that are uploaded on YouTube by Jokowi sympathizers.

Based on data from the electoral commission of the Republic of Indonesia, in the second round of Jakarta 
Governor Election 2012 the number of those who did not vote down compared to the first round. The number of abstentions declined because the turnout in the second round rose $2.2 \%$ to $66.8 \%$, while in the first round turnout is only $64.6 \%$. Percentage abstentions second round is down about $3.1 \%$ to $33.2 \%$. While in the first round and then, the percentage of non-voters reached $36.3 \%$. Number of those eligible to vote in the second round was $6,996,951$ and the participation rate is $66.8 \%$ or $4,667,991$ people use their right to vote in 15,059 polling stations (Afifah, 2012). The decrease in the number of voters in the Jakarta Governor Election 2012 is interesting to study to see if the young people began to participate in the elections because of use of social media in political campaigns. This research aims to determine the effect of social media content against the level of interest and knowledge of young voters about political information in Jakarta Governor Election 2012.

\section{LITERATURE REVIEW}

\subsection{Exposure to Political Information in Mass Media}

From not knowing to knowing after consuming media can be considered one type of media effects. According to Graber (1980), people who are exposed to the mass media already possess a fund of knowledge and attitudes, which they bring to bear on new information. Political information, which many people look for in the media are about candidates and campaigns (Baek and Wojcieszak, 2009; Kim and Vishak, 2008). Exposure to political information on television and political websites is likely to increase people's campaign interest (Bartels, 1993). "Interest, in turn, affects turnout even when one controls for political knowledge" (Verba, Scholzman, and Brady, 1995). "Media use (television and newspapers) is instrumental in increasing political knowledge, efficacy and even voter turnout" (McLeod and McDonald, 1985).

Classic democratic theories of voting behavior suggest a focus on the provision of accurate information necessary for informed and rational voting decision (Berelson, 1966). "Exposure increases political knowledge, which in turn increases turnout" (Delli Carpini and Keeter, 1996; Verba, Schlozman and Brady, 1995) "because people know where, how, and for whom to vote. Furthermore, knowledgeable people are more likely to perceive differences between candidates and thus less likely to abstain due to indifference" (Palfrey and Poole, 1987).
The media can help increase voter participation by not only providing citizens with information to make informed voting decision, but by stimulating interest in elections. Scholars who have studied the media over time generally conclude that the media reinforces political interest and voting intentions, because political interest, voting and learning from the media reinforce each other (Weaver, 1996). High SES people are more informed and more likely to participate in politics than low SES people are (Verba and Nie, 1972). Lower educated groups might also be disadvantaged in comparison with the higher educated groups because of the knowledge gap phenomenon. In elections, the lower educated groups might not know as much about the issues and candidates as the higher educated groups, and thus be less able to vote in their own interests and also more susceptible to being manipulated by political advertisements against their own interests (Patterson and McClure, 1976).

Exposure to political information in the media can increase people's interest in the political campaign. This statement was made by experts after conducting research to determine the effect of exposure to political information in various media on voters' turnout. Furthermore, experts say the media exposure will cause users to be aware and understand the political information, which in turn will affect the political participation.

\subsection{Social Media Effects, Engagement, and Parti- cipation}

Social media is a general term covering nontraditional ways of delivering information. The choice of content in social media can be a powerful predictor for voters. The ease of internet access and diversity of media choice can be a predictor of increased knowledge. Political knowledge and turnout in elections closely related due to exposure to political information can motivate people to vote (Prior, 2005). Social media increases the political knowledge and encourage involvement in election.

"Social media is a phenomenon that could dramatically change how and how many young people participate civically, including voting" (Kahne and Middaugh, 2012). However, unlike the political participation in traditional political era, participatory politics in the era of social media are more interactive, peer-based, and not guided by political parties or mass media. These young people will form a new political group online, deliver opinions and thoughts of politics 
through blogs, share political videos via their social networks or provide commentary on the message conveyed through social media. Youth can write and spread the information they get from traditional media, distributed between their networks, and provide comments to help their peers, think about information or issues in society.

Social media platforms, as emerging political spaces, have paved the way for the re-conceptualization of political engagement, especially among the youth (Lim, 2009). Youth participatory character, particularly blogging, social networking and content sharing, has encouraged more people to be involved in political issues and has contributed to changing the mode of protest from streets to cyberspace. Continuously evolving technologies as well as the changing approach of the public toward civic engagement, a social undercurrent, has redefined social movements and political participation (Rheingold, 2002; Jenkins 2008), especially among the youth, who consider these technological advancements as demotic. If before, young people were more likely to identify with, join organized groups with a set of ideals, and express their concern through unconventional political actions, such demonstration and boycotts (Wattenberg, 2008). The youth today are more likely to reject dogmatism avoid commitment and express their indignation through rather conventional and convenient political actions, such as conversations, group discussions and volunteering. However, this is not to say that the youth are becoming less concerned or are willing stake less. In many ways, the social platforms of the internet amplify these alternatives (conventional political actions) and reinforce and rationalize the view that political participation does not necessarily need to be inconvenient (Lim, 2009). Althaus and Tewksbury (2000) support this statement by saying users have the ability to control their information usage on internet and young people use the web for surveillance of political information.

Social media enables young people to discuss with peers who have similar interests and views on a global scale. "This social interaction creates opportunities for individuals to gather information about politics that allows them to live beyond personal resource constraints, thereby supporting the political activity of many people" (McClurg, 2003). "Social interaction has a value added effect that helps people better understand when personal characteristics and resources contribute to involvement. Social exchange variably exposes people to a social supply of information that broadens their exposure to and understanding of politics" (Huckfeldt and Sprague, 1995; Huckfeldt, 2001). Since individual understanding, information, resources, and ability are inherently limited, this means that social interaction provides people with another opportunity to accrue resources that lower the barriers to political participation. "Social interaction exposes people to a different set of politically relevant information and stimuli than they possess individually" (Huckfeldt, 2001; Mutz, 2002). Benkler (2006) discusses how the emergence of the networked public sphere allows individuals to take advantage of capabilities that make them greater participants in the conversation. The technology allows individuals the means not only to build a network of connections but also to be influenced and to influence that network exponenttially (Bond et al., 2012).

Trend researches on social media focus more on social-media impact on society, especially on young people as a way to participate in politics and engage in social movements as citizens. The influence of the internet and attempts to gain the support of young people and as a means to raise funds, influence of social media and a new style of political participation, as well as the influence of social media exposure and interpersonal relationships with voting behavior. Research on the effect of social media has been widely performed in developed countries or Western countries and still rarely done mainly in Indonesia. It encourages researchers to do study on that topic especially in Jakarta. Due to the high level of the digital divide between urban and rural areas, Jakarta selected as the study site because it is considered appropriate to research topics. Moreover, as the capital city of Indonesia, the number of people accessing the internet in Jakarta is $71.22 \%$ based on the level of education from high school to university and this is the highest percentage compared to other cities in Indonesia (Badan Pusat Statistik, 2014).

\section{RESEARCH METHODS}

\subsection{Operationalization Definitions}

\subsubsection{Social Media and Social Media Content}

Social media is media that "content is created and distributed through social interaction" (Haynes and Pitts, 2009). Social media is "lined up internet applications that are made based on web 2.0 technology and allows the exchange of information from each internet users" (Kaplan and Haenlein, 2010). Social media allows us to interact, collaborate, 
and participate actively in fluid communities (Wood, 2009). In the context of electoral web sphere, "social media may facilitate engagement in the election process through three interrelated activities: provision of election-related information, opportunity for discussion and debate, and opportunity for undertaking election-related political action" (Foot and Schneider, 2006).

Operationalization of the definitions of social media content is modified from Foot and Schneider (2006) as well from Foot et al. (2007). First, inform is the most basic function of political communication online. Social media is providing opportunities for social media users to become informed about political actors, issues positions or the election process. Second, engagement means social media producer provides menus that facilitate a connection between users and candidate in order that social media users may interact directly with candidate. Finally, participating means social media producer are providing menus that enables social media users to participate actively and directly in online campaign activities, which supports the candidate.

\subsubsection{Political Knowledge as a Form of Cognitive Effects}

The effects arising due to consumption of media content is called media effects. Potter stated, "mediainfluenced effects are those things that occur as a result from media influence. The term is often used to denote changes in individuals that are caused by exposure to the media" $(2012$, p. 38$)$. While political knowledge as one of the cognitive effects of media, is measured by the following points:

1. Exposure here is defined as the act when someone is using social media or contact with information through some communications medium. Because of the usage of social media, he/she is exposed to social media content. Social media exposure is an act of being subjected to or being influenced by social media content. Exposure is characterized by:

a. Total time spent on social media

b. Number of times social media is accessed

2. Knowledge is a familiarity with someone or something after contact and give attention to the media message. Knowledge of social media content can be understood as an event that occurs after exposure to social media or something that happened as a direct result of the influence of social media. When using social media, visitors will be exposed to social media content; then they will follow and understand messages in social media so the visitors ultimately gain knowledge and become aware of something.

\subsection{Hypothesis}

This research aims to find out the effect of social media content against the level of interest and knowledge of young voters about political information, therefore the following null hypothetical will be tested:

1. There is no difference in political knowledge between university students who use social media to find information about the elections and those who do not.

2. There is no difference in political knowledge between university students who become candidate's friends, follower, viewers or players than those who do not.

3. There is no difference in political knowledge between university students who post 'like' and 'comment' and those who do not.

4. There is no difference in the rate of interest of political information between university students who use social media and those who do not.

\subsection{Data Collection Technique}

This research was quantitative research by testing hypothesis to see the correlation between two variables. Students, especially students in grade 'A' university department, was chosen as research subjects because due to their educational background young voters are expected to vote rationally. This means that they will not carelessly dropped the option to vote for a candidate but rather look at the record of accomplishment or the characteristics of the candidates to be selected. The young voters are technologically literate to use the social media while deciding whom to vote. Based on data from National Accreditation Institution (Badan Akreditasi Nasional Perguruan Tinggi, 2013), in Jakarta, there were 30 departments in 14 universities accredited 'A' for 2015. While the total population by age (17-22 years old) were 913,959 with 439,976 are male and 473,983 are female (Badan Pusat Statistik, 2010). Then by using Krejcie and Morgan's formula the number of samples to be calculated. By using 5\% margin of error and 95\% confidence level, the number of samples required were 385 students. Therefore, with a sample of 385 was needed 12-13 students in each department which will be determined by lottery.

\subsection{Data Analysis Technique}

Researchers is interested in describing association between variables therefore Pearson correlation will be used to measure association between these two variables also t-test and regression analysis will be used in this study. 


\section{DATA ANALYSIS AND INTERPRETATION}

There are $116(30.1 \%)$ were male and 269 respondents $(69.9 \%)$ were female. The majority of respondents was $20-22$ years those were 233 students $(60.5 \%)$. Three hundred and forty-five respondents (345 or $89 \%$ ) had social media accounts for more than $>2$ years, 34 respondents $(9 \%)$ had accounts $1-2$ years, and 3 respondents, each have an account media social for 1-6 months and 7-12 months.

Related the frequency in a day visiting social media, the majority of respondents said social media was visited more than 4 times in a day. There are 173 or $44.9 \%$ respondents used Facebook for $>4$ times a day and this answer is the highest compared to other options. Twitter most visited by respondents $>4$ times a day as stated by 185 or $48.05 \%$ respondents. Likes Twitter and Facebook, the amount of visiting YouTube in a day mostly is $>4$ times a day done by 126 or $32.73 \%$ respondents. While on online game 'Save Jakarta', the most visiting is $>4$ times a day done by 125 or $32.47 \%$ respondents.

On Facebook, the length of time using this social media regarding Jakarta Governor Election 2012 the most is for $\geq 600$ minutes or $\geq 10$ hours as done by 201 or $52.21 \%$ respondents. Twitter most used by respondents for $\geq 600$ minutes or $\geq 10$ hours as stated by 198 or $51.43 \%$ respondents. Most respondents spent time for $\geq 10$ hours ( $\geq 600$ minutes) when they used YouTube to get information about Jakarta Governor Election 2012. A similar case also happened in the online game 'Save Jakarta'. Most respondents used this type of social media for $>10$ hours, as stated by 153 (39.74\%) people.

In Figure 1 can be seen that the greatest knowledge about politics occur when respondents were using social media more than 4 times a day. On Facebook, there are 172 or $44.9 \%$ respondents who said that they got the media influence after using social media more than 4 times a day, while on Twitter; there are 164 or $42.6 \%$ of respondents. One hundred and twenty-six (126 or $32.7 \%$ ) of respondents said YouTube is affected, and 107 or $27.8 \%$ of respondents stated gained influence after playing the online game 'Save Jakarta' $>4$ times a day. Based on this result, it can be said that the more often a person uses social media, the more likely he/she will be influenced by media.

The same thing happened on the results of the cross tabulation between the length of time using social media with political knowledge as can be seen in
Figure 2. Respondents became know about political information after using social media $\geq 600$ minutes in a day. On Facebook, it is stated by 202 or $52.5 \%$ respondents, while on Twitter, there are 198 or $51.4 \%$ of respondents who stated it, 184 or $47.8 \%$ of respondents admitted after using YouTube, and 152 or $39.7 \%$ of respondents said the same thing after they played online game 'Save Jakarta'. From this result, it can be said that the longer people are using social media, the more likely he/she will get the political knowledge.

Regarding political information about Jakarta Governor Election 2012 in social media, majority of respondents said Facebook was social media that most provided information about Jakarta Governor Election 2012 compared with other types of social media. One hundred fifty seven (157 or $40.8 \%$ ) respondents chose Facebook as the most social media provided information about Jakarta Governor Election 2012, while respondents who chose Twitter are 134 or $34.8 \%$. YouTube stated by 76 or $19.7 \%$ respondents as the most social media that provided this information and 18 or $4.7 \%$ respondents chose online game 'Save Jakarta' as the most social media provided information about Jakarta Governor Election 2012.

\subsection{Provision of Election-Related Information and Political Knowledge}

To know the relationship between social media use to find information politics with political science as a form of cognitive effects of social media, next researchers tested following hypothesis in statistics.

$\mathrm{H}_{0}$ : University students who use social media to get information will not exhibit political knowledge about elections more than university students who do not $(\mathrm{p}=0)$

$\mathrm{H}_{1}$ : University students who use social media to get information will exhibit political knowledge about elections more than university students who do not $(\mathrm{p} \neq 0)$

There is at least a $99.9 \%$ chance, a true relationship between using Facebook with knowledge of political information about Jakarta Governor Election 2012, r $=.90$, which can be considered a large effect. While on Twitter, there is at least a $99.9 \%$ chance that there is a true relationship between using Twitter with knowledge of political information about Jakarta Governor Election 2012, $\mathrm{r}=.89$, which can be considered a large effect. Knowledge of political 


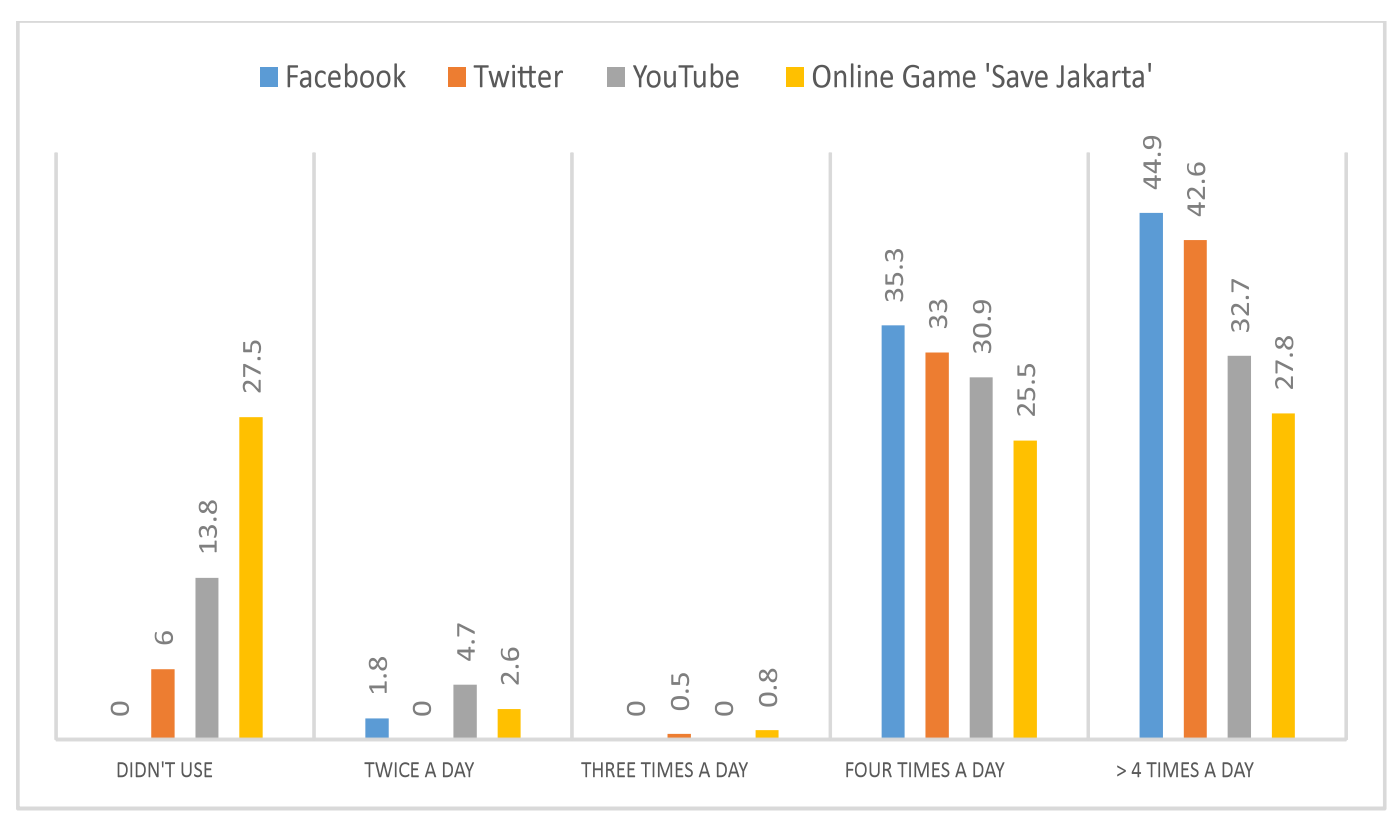

Figure1. Cross-Tabulation between Frequency and Political Knowledge

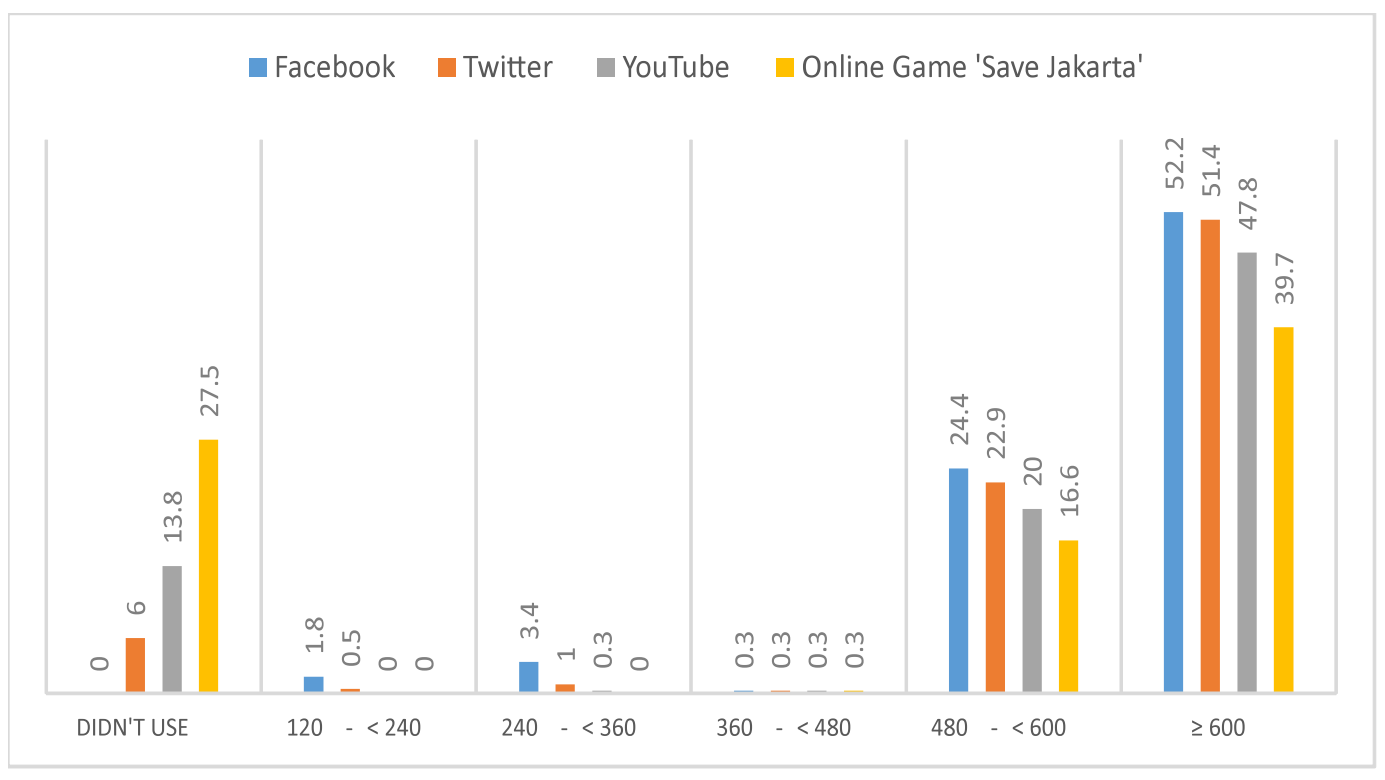

Figure 2. Cross-Tabulation between Duration (in Minutes) and Political Knowledge

information about Jakarta Governor Election 2012 also has relationship with viewing YouTube, $r=.82$, which can be considered a large effect. Chances of the relationship between viewed YouTube with knowledge of political information is at least a $99.9 \%$. Playing online game 'Save Jakarta' were correlated with knowledge of political information about Jakarta Governor Election 2012, $r=.78$ which can be considered a large effect. Chances of the relationship between playing online game 'Save Jakarta' with knowledge of political information is at least a $99.9 \%$ (can be seen in Table 1).

Statistical testing gained that there is very strong evidence against null hypothesis or reject $\mathrm{H}_{0}$ because $p$-value $<.05$ so it can be said that students who use media social than others who do not, tend to have political knowledge. Students who use social media, tend to have more political knowledge than those who do not. 
Table 1. Summary Output of Pearson Correlation and Regression Test Results between Using Social Media to Get Political Information with Political Knowlegde

\begin{tabular}{lccc}
\hline \multicolumn{1}{c}{ Using Social } & \multicolumn{3}{c}{ Political Knowledge } \\
\cline { 2 - 4 } \multicolumn{1}{c}{ Media } & Pearson's $\boldsymbol{r}$ & P-Value & Chances \\
\hline Facebook & .899600425 & $7.0994 \mathrm{E}-140$ & $99.9 \%$ \\
Twitter & .889422443 & $2.7536 \mathrm{E}-132$ & $99.9 \%$ \\
YouTube & .824003949 & $1.56258 \mathrm{E}-96$ & $99.9 \%$ \\
Online Game & .77532043 & $1.90877 \mathrm{E}-78$ & $99.9 \%$ \\
'Save Jakarta' & & & \\
\hline
\end{tabular}

Note. $\alpha=0.05$

\subsection{Online Participation in Social Media as an Indicator of Political Knowledge}

One of the uniqueness of social media and other media types do not have is the ability to engage users. Social media is able to give the opportunity to the users to do online political action by becoming a supporter of the candidate. Therefore, next researchers want to know the relationship between become candidate's friends in social media with political knowledge. Hypotheses to be tested are:

$\mathrm{H}_{0} \quad$ University students who become candidate's friends, followers, subscribers or players will not political knowledge more than university students who do not $(p=0)$

$\mathrm{H}_{1} \quad$ University students who become candidate's friends, followers, subscribers or players will exhibit political knowledge more than university students who do not $(p \neq 0)$

The results of statistical tests using Pearson correlation coefficient and regression to determine whether this hypothesis is accepted or rejected can be seen in Table 2 . There is correlation between become candidate's friends on Facebook and knowledge of political information especially regarding Jakarta Governor Election 2012. Become candidate's friends on Facebook were correlated with knowledge or knowledge about political information, $r=.93$, which can be considered very highly correlated. Knowledge of political information about Jakarta Governor Election 2012 has relationship with become candidate's follower on Twitter $(\mathrm{r}=.89)$, which can be considered a large effect. Chances of the relationship between become candidate's follower on Twitter with knowledge of political information is at least a $99.9 \%$. Subscribe to candidate's channels on YouTube were correlated with knowledge of political information about Jakarta Governor Election 2012, $r=.83$, can be considered highly correlated. Chances of the relationship between subscribe to candidate's channels with knowledge of political information is at least a $99.9 \%$. On online game 'Save Jakarta', there is at least a
99.9\% chance, a true relationship between play online game 'Save Jakarta' with knowledge about political information especially regarding Jakarta Governor Election 2012, $\mathrm{r}=.78$ which can be considered a strong effect.

Table 2. Summary Output of Correlation and Regression Test Results between Become Candidate's Friends, Followers, Subscribers, or Players on Social Media with Political Knowledge

\begin{tabular}{lrrr}
\hline \multicolumn{1}{c}{ Engagement in } & \multicolumn{3}{c}{ Political Knowledge } \\
\cline { 2 - 4 } Social Media & Pearson's $\boldsymbol{r}$ & \multicolumn{1}{c}{ P-Value } & Chances \\
\hline $\begin{array}{l}\text { Become candidate' } \\
\text { friends on Facebook }\end{array}$ & 0.9280845 & $2.1156 \mathrm{E}-166$ & $99.9 \%$ \\
$\begin{array}{l}\text { Become candidate's } \\
\text { follower on Twitter }\end{array}$ & 0.8928160 & $9.889 \mathrm{E}-135$ & $99.9 \%$ \\
$\begin{array}{l}\text { Subscribe to } \\
\text { candidate's channel } \\
\text { on YouTube }\end{array}$ & 0.8322613 & $1.8952 \mathrm{E}-112$ & $99.9 \%$ \\
$\begin{array}{l}\text { Play online Game } \\
\text { 'Save Jakarta' }\end{array}$ & 0.7753204 & $2.2443 \mathrm{E}-187$ & $99.9 \%$ \\
\hline
\end{tabular}

Note. $\alpha=0.05$

Regression test results also get $p$-value $<.05$ it means there is very strong evidence against null hypothesis or reject $\mathrm{H}_{0}$ and accept $\mathrm{H}_{1}$. Based on the statistical test it can be said that university students who become candidate's friends, followers, subscribers or players will exhibit more political knowledge than university students who do not.

Next the researchers did the test statistic to figure out the correlation between another form of online political action, post 'like' and comments, with political knowledge. The hypothesis to be tested are:

$\mathrm{H}_{0}$ : University students who post 'like' and 'comments' will not exhibit political knowledge about elections more than university students who do not post $(p=0)$

$\mathrm{H}_{1}$ : University students who post 'like' and 'comments' will exhibit political knowledge aboue elections more than university students who do not post $(p \neq 0)$

The results of hypothesis testing is there is at least a 97.5\% chance, a true relationship between post 'like' on Facebook with knowledge of political information about Jakarta Governor Election 2012, $\mathrm{r}=.83$, which can be considered a large effect. On Twitter, there is at least a $99.8 \%$ chance that there is a true relationship between post 'favorite' on Twitter with knowledge of political information about Jakarta Governor Election $2012, \mathrm{r}=.85$, which can be considered highly correlated. Knowledge of political information about Jakarta Governor Election 2012 also has relationship with post 'like' on YouTube, $\mathrm{r}=.80$, which can be 
considered highly correlated. Chances of the relationship between posts 'like' on YouTube with knowledge of political information is at least a $99.8 \%$. Post 'like' on online game 'Save Jakarta' were correlated with knowledge of political information about Jakarta Governor Election 2012, $r=.79$ which can be considered a large effect. Chances of the relationship between posts 'like' on online game 'Save Jakarta' with knowledge of political information is at least a $99.9 \%$. Based on the statistical test, there is very strong evidence against null hypothesis or reject $\mathrm{H}_{0}$ because $p$-value $<.05$ and it can be said students who post 'like' on social media tend to exhibit more political knowledge than students who do not.

Related to post comments in social media there is very strong evidence against null hypothesis or reject $\mathrm{H}_{0}$ because $p$-value $<.05$ (can be seen in Table 3 above). There is a true relationship between post 'comments' on Facebook $(r=.85)$ and post 'reply' on Twitter $(\mathrm{r}=.84)$ with knowledge of political information in elections. Chances of the relationship between post 'comments' or post 'reply' and the knowledge is at least a $99.9 \%$. Furthermore, post 'comments' on YouTube $(\mathrm{r}=.86)$ were correlated with knowledge of political information regarding Jakarta Governor Election 2012. The relationship between these variables with the knowledge of political information can be considered highly correlated. Students, who post 'comments' on social media, especially when using Facebook, Twitter, or YouTube, tend to have more political knowledege than students who do not post.

\subsection{Level of Interest in Political Issues Before and After Using Social Media}

In this section, the researchers want to find out whether there are differences in the level of interest in political issues before using social media and after using social media. By knowing the change in interest level between before and after using social media it can be seen the presence or absence of social media effect. In addition, it is interesting because during this time the youth was known as a group that does not care about politics. If social media can change the level of interest in political information, then in the future, social media can be maximized as a medium to conduct political lesson. The hypothesis to be tested with respect to this goal are:

$\mathrm{H}_{0}$ : There is no difference in the level of interest with political information before and after using social media $\left(\mu_{\text {before }}=\mu_{\text {affer }}\right)$

$\mathrm{H}_{1}$ : There are differences in the level of interest with political information before and after the use of social media $\left(\mu_{\text {before }} \neq \mu_{\text {after }}\right)$

On Facebook, the different on level of interest regarding political information before and after using Facebook is significant. P-value two tail $=1.4418 \mathrm{E}-$ 180 or $\mathrm{P}$-value two tail $<.05$. It means $99.9 \%$ chance that level of interest regarding political information before using Facebook is different with level of interest after using Facebook. We can reject the null hypothesis because $\mathrm{t}$-Test $=-53.6762$ which means $\mathrm{t}$ Test less than $\mathrm{t}$ critical two-tail $=1.96616$.

Table 3. Summary Output of Correlation and Regression Test Results between Post 'Like' and 'Comment' (Online Participation) on Social Media with Political Knowledge

\begin{tabular}{|c|c|c|c|c|c|c|}
\hline \multirow{2}{*}{ Social Media } & \multicolumn{2}{|c|}{ Pearson's $r$} & \multicolumn{2}{|c|}{ P-Value } & \multicolumn{2}{|c|}{ Chances Correlation } \\
\hline & 'Like' & 'Comment' & 'Like' & 'Comment' & 'Like' & 'Comment' \\
\hline Facebook & 0.828638 & 0.852587 & 0.0246511 & $3.34968 \mathrm{E}-14$ & $97.5 \%$ & $99.9 \%$ \\
\hline Twitter & 0.845420 & 0.839209 & 0.0019253 & 4.37207E-33 & $99.8 \%$ & $99.9 \%$ \\
\hline YouTube & 0.797239 & 0.862264 & 0.001925 & 4.37207E-33 & $99.8 \%$ & $99.9 \%$ \\
\hline Online Game & 0.785704 & - & $3.4092 \mathrm{E}-124$ & - & $99.9 \%$ & 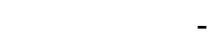 \\
\hline
\end{tabular}

Note. $\alpha=0.05$

Table 4. Summary Table T-Test: Paired Two Sample for Means of Level of Interest with Political Information Before and After Using Social Media

\begin{tabular}{|c|c|c|c|c|}
\hline No. & Social Media & $\mathbf{P}(\mathrm{T} \leq \mathrm{t})$ two tail & t-Test & t Critical \\
\hline 1. & Facebook & $1.4418 \mathrm{E}-180$ & -53.6762699 & 1.966160961 \\
\hline 2. & Twitter & $7.5702 \mathrm{E}-143$ & -42.59160084 & 1.966557085 \\
\hline 3. & YouTube & $5.2558 \mathrm{E}-160$ & -51.46650487 & 1.9671568 \\
\hline & Online game 'Save Jakarta' & 1.6904E-133 & -46.65070789 & 1.968533975 \\
\hline
\end{tabular}

Note. $\alpha=0.05$ 
Similarly, on Twitter, there is significantly different in level of interest regarding political information before and after use Twitter. P-value two tail $=7.5702 \mathrm{E}-143$ or P-value two tail $<.05$. It means $99.9 \%$ chance that level of interest regarding political information before and after using Twitter is significantly different. We can reject the null hypothesis because t-Test = 42.5916 which means $\mathrm{t}$-Test less than $\mathrm{t}$ critical twotail $=3.7851 \mathrm{E} 143$.

T-test paired two sample for means also get there is significantly different in level of interest regarding political information before and after use YouTube in Jakarta Governor Election 2012. P-value two tail = $5.2558 \mathrm{E}-160$ or P-value two tail $<.005$. It means 99.9\% chance that level of interest regarding political information before and after using YouTube is significantly different. We can reject the null hypothesis because $\mathrm{t}$-Test $=-51.4665$ which means $\mathrm{t}$-Test less than $t$ critical two-tail $=1.96715$. On online game 'Save Jakarta', the different on level of interest regarding political information before and after using online game 'Save Jakarta' is significant. P-value two tail $=1.6904 \mathrm{E}-133$ or $\mathrm{P}$-value two tail $<.05$. It means $99.9 \%$ chance that level of interest regarding political information before using online game is different with level of interest after using online game in Jakarta Governor Election 2012. Moreover, we can reject the null hypothesis because $\mathrm{t}$-Test $=-46.6507$ which means $\mathrm{t}$-Test less than $\mathrm{t}$ critical two-tail $=1.96853$.

Based on statistical tests were conducted to determine the presence or absence of differences in the level of interest before and after the use of social media, it can be seen that on Facebook, Twitter, YouTube, and online game 'Save Jakarta' there are differences in the level of interest. Therefore, we can reject the null hypothesis because t-test less than $t$ critical two-tail. It can be concluded that social media significantly affected the level of interest regarding political information.

\section{DISCUSSIONS}

Results of hypothesis testing state that political information in social media, menus available in social media that allows visitors to interact directly with the candidate, and menus that allow visitors to participate actively and directly in an effort to support the candidates, have a relationship with understanding of the message contained in social media used in Jakarta Governor Election 2012. The involvement and active participation of social media visitors can happen because "social media have the advantage to combine the various activities that integrate technology, social interaction, and construction of words and pictures" (Anvil Media, 2009). Unlike the political participation in traditional political era, participatory politics in the era of social media are more interactive, peer-based, and not guided by political parties or mass media (Bennett, 1998). The internet is also improving access to information; allows users to perform political expression and political action online, affiliated with the citizens who support, comfort or novelty to engage online, all of which can attract people who are disillusioned with traditional ways of participating in politics (Boulianne, 2009). Moreover, many agree that political information and participation are important to democracy (Cassel and Lo, 1997).

Menus that allows visitors to interact directly with candidates such as menus that allow them become candidate's friends on Facebook, become candidate's followers on Twitter, or can subscribe to candidate's channel on YouTube, become one of the predictors for knowledge of political information regarding election. "Internet for its ability to enhance voter involvement and reengage voters through interactivity" (Corrado and Firestone, 1996). The internet allows individuals to quickly and easily go to a candidate's website and contribute electronically (Haynes and Pitts, 2009). In addition, apathetic users, in particular, were more likely to see increased interactivity as a sign of greater candidate responsiveness and trustworthiness (Sundar et al., 1998).

Menus that can provide opportunities for visitors to participate actively by sending symbol 'like' or comments on social media becomes one of the predictors in building knowledge of election-related political information. Youth see that engage in participatory politics by doing activities such as status updates, tweets, share, post comments, etc. are ways to get involved in politics (Bennett, 1998). Internet reduces the barriers to participation and thus reduces social inequality that exists in public life (Tolbert and McNeal, 2003).

On the advantages of social media that allows users to perform online participation, the opportunities presented by social media is increasingly driven by frequent and the length of a person's use of social media. One's desire to become friends, followers, subscribers, and players in the social media increasingly driven by the longer and the more often he/she uses social media. In other words, more frequently and the longer a person uses social media will encourage him/her to participate actively online 
by becoming friends, followers, subscribers, or players in a social media account. A growing portion of the population has chosen to learn about and contribute to political life through digital technologies (Howard, 2005). Discussions with friends who are interested or active in politics can help people learn about "the reasons for participating while reinforcing the idea that such behavior is desirable among one's peers" (McClurg, 2003).

Regarding with the age, young people are charged with being disengaged from conventional politics. Young people are the most politically disengaged of all citizens, and this disengagement contributes to a growing sense of apathy and even alienation (Ward, 2007, p. 137). Nevertheless, it turns out political information submitted through social media has changed the level of interest of young voters on the political issues in Jakarta Governor Election 2012. RM Negrine (2008) in his book "The Transformation of Political Communication: Continuities and Changes in Media and Politics" (as cited from Susilo, 2016) states that political messages spread through social media transformed into pop culture can encourage the involvement of young people. Political information was regarded as heavy and unattractive, has been transformed into information that is lighter and easier to digest thus attracting the attention of young voters in Jakarta Governor Election 2012.

Facebook has become a social media the most trustworthy than other types of social media. This is because Facebook has advantages over other types of social media such as, users can create a profile, add other users as 'friends', exchange messages, update status, uploading or tag photos, share videos, and receive notification when friends in contact do something on their Facebook account. Additionally, users may join common-interest user groups, and categorize their friends into lists (Facebook, 2015). Many citizens rely on their trusted friendship network and are vetting official information they hear through their friendship ties. They are paying attention to news and information shared by their trusted online contacts. Social networking platform has become a way to validate information as well as have become a tool to increase awareness of a particular issue or topic because it is attractive in their social network. Social media are additional channels for public engagement and participation as well as increased transparency (Mergel, 2012). This "social interaction creates opportunities for individuals to gather information about politics that allows them to live beyond personal resource constraints, thereby supporting the political activity of many people" (McClurg, 2003). "Social exchange variably exposes people to a social supply of information that broadens their exposure to and understanding of politics" (Huckfeldt and Sprague, 1995; Huckfeldt, 2001). Since individual understanding, information, resources, and ability are inherently limited, this means that social interaction provides people with another opportunity to accrue resources that lower the barriers to political participation.

\section{CONCLUSION}

Advantage of computer-mediated communication in social media is potential for intensifying more interactive, two-way communication flows between citizens, representatives, political actors and members of civil society movements. Computer-mediated communication opens up new methods for political activity, like submitting electronic petitions, writing and distributing e-mails, and participating in online opinion polls. Social media are certainly an instrument in providing direct information and engagement, but what makes them special is that they also signal flexibility, care for marginal voters, and political entrepreneurship. Internet-literate urban society is expected to prefer social media as a reference to know more about the candidates in political elections. The virtual world is a huge space for campaign that can accommodate unlimited number of masses. Each individual can become a spoke person for candidates they support.

Political messages spread through social media transformed into pop culture can encourage the involvement of young people. Social media has changed the political information that is considered unattractive and too heavy for young voters, into something lighter and popular that attract the attention of young people. Through social media, young voters learn about the political information such as candidate profile, candidate manifesto, voting process, electoral campaign process, and comparison of issue positions that eventually led them to participate both online and offline by voting in elections.

To encourage the involvement of young voters in the election, candidates who use social media, the content should contain information about candidates and elections; there are menus that can engage users, and menus that can encourage user participation online. This engagement such as the availability menus as contact information, opportunities for users to join or become members of the organization, opportunities 
for users to become volunteers, and the option of donation to enable users to give money to the campaign. In addition, it is necessary the availability menus which allow voters or social media users to make a public statement, to engage in digital promotion, to share link to friends or others, to post 'like' and to write give 'comment' on candidate's social media accounts.

\section{REFERENCES}

Afifah, Riana. (2012, September 27). Pilkada DKI putaran kedua, golput Jakarta menurun. Retrieved from http://megapolitan.kompas.com/read/ 2012/09/27/14505319/Pilkada.DKI.Putaran. Kedua.Golput.Jakarta.Menurun

Althaus, S. L., \& Tewksbury, D. (2000). Patterns of internet and traditional news media use in a networked community. Political Communication, 17, 21-45.

Anvil Media. (2009). Resources: SEM glossary of terms. Retrieved from http://www.anvilmediainc.com/search-engine-marketing-glossary. $\mathrm{html}$

Badan Akreditasi Nasional-Perguruan Tinggi (2013). Hasil akreditasi. Retrieved August 19, 2013 from http://ban-pt.kemdiknas.go.id/hasil-akreditasi/en/hasil-pencarian.php

Badan Pusat Statistik. (2010). Penduduk menurut umur tunggal, daerah perkotaan/pedesaan, dan jenis kelamin provinsi DKI Jakarta. Retrieved August 6, 2013 from http://sp2010.bps.go.id/ index.php/site

Baek, Y. M., \& Wojcieszak, M. E. (2009). Don’t expect too much! Learning from late night comedy and knowledge item difficulty. Соттиnication Research, 36, 783-809.

Bartels, Larry M. (1993, June). Messages received: The political impact of media exposure. The American Political Science Review, 87(2), 267285. Retrieved from http://www.jstor.org/stable/ 2939040

Benkler, Yochai. (2006). The wealth of networks: How social production transforms markets and freedom. Boston: Yale University Press.

Berelson, B. (1966). Democratic theory and public opinion. In B. Berelson and M. Janowitz (Eds.), Reader in public opinion and communication (pp. 38-42). New York: The Free Press.

Bond, R. M., Fariss, C. J., Jones, J. J., Kramer, A. D. I., Marlow, C., Settle, J. E., \& Fowler, J. H. (2012). A 61-million-person experiment in social influence and political mobilization. Nature, 489, 295-298.
Boulianne, Shelley. (2009). Does internet use affect engagement? A meta-analysis of research. Political Communication, 26(2), pp. 193-211.

Carlisle, Juliet, E., \& Patton, Robert C. (2013, Dec.). Is social media changing how we understand political engagement? An analysis of Facebook and the 2008 presidential election. Retrieved from http://www.jstor.org/stable/23612065

Corrado, A., \& Firestone, C. (1996). Elections in cyberspace: Toward a new era in American politics. Washington, DC: Aspen Institute.

Cassel, C. A., \& Lo, C. C. (1997). Theories of political literacy. Political Behavior, 19, 317-335.

Dalager, Jon K. (1996, May). Voters, issues, and elections: Are the candidates' messages getting through? The Journal of Politics, 58(2), 486515.

Delli Carpini, Michael X., \& Keeter, Scott. (1996). What Americans know about politics and why it matters. New Haven: Yale University Press.

Facebook. (2015). Newsroom: Products. Retrieved from http://newsroom.fb.com/products/

Foot, Kristen, \& Schneider, Steven. (2006). Web campaigning. Cambridge: MIT Press.

Foot, Kristen A., Schneider, Steven M. and Dougherty, Meghan. (2007). Online structure for political action in the 2004 U.S. congressional electoral web sphere. In Randolph Kluver, Nicholas W. Jankowski, Kirsten A. Foot \& Steven M. Schneider (Ed.), The internet and national elections: A comparative study of web campaigning (pp. 92-104). New York: Routledge.

Gong, Rachel. (2011). Internet politics and state media control: Candidate weblogs in Malaysia. Sociological Perspectives, 54(3), 307-328. Retrieved from http://www.jstor.org/stable/ 10.1525/sop.2011.54.3.307

Graber, D. A. (1980). Mass media and American politics. Washington, DC: Congressional Quarterly.

Haynes, Audrey A., \& Pitts, Brian. (2009, Jan.). Making impression: New media in the 2008 presidential nomination campaigns. PS: Political Science and Politics, Vol. 42, No. 1, pp. 53-58. Retrieved from http://www.jstor/org/stable/ 20452373

Huckfeldt, Robert, \& Sprague, John. (1995). Citizens, politics, and social communication: Information and influence in an election campaign. Cambridge, UK: Cambridge University Press.

Huckfeldt, Robert. (2001). The social communication of political expertise. American Journal of Political Science, 45(2), 425-439. 
Jenkins, Henry. (2008). Convergence culture: Where old and new media collide. New York: New York University Press.

Kahne, Joseph, \& Middaugh, Ellen. (2012). Digital media shapes youth participation in politics. The Phi Delta Kappa, 94(3), 52-56. Retrieved from http://www.jstor.org/stable/41763677

Kaplan, Andreas M., \& Haenlein, Michael. (2010, January-February). Users of the world, unite! The challenges and opportunities of social media. Business horizons, 53(1), 59-68. Kelley School of Business, Indiana University. Retrieved from http://www.sciencedirect.com/ science/article/pii/ S0007681309001232

Kim, Y. M., \& Vishak, J. (2008). Just laugh! You don't need to remember: The effects of entertainment media on political information acquisition and information processing in political judgment. Journal of Communication, 58, 338-360.

Kompas.com. (2012, July 16). Hasil hitung cepat Pilkada DKI: Ada yang popular, ada yang berbenah. Retrieved from http://megapolitan. kompas.com/read/2012/07/16/11253159/Ada. yang.Populer.Ada.yang.Berbenah

Lim, Niel Nino. (2009). Novel or Novice: Exploring the contextual realities of youth political participation in the age of social media. Philippine Sociological Review, 57, 61-78. Retrieved from http://www.jstor.org/stable/23898344

McClurg, Scott D. (2003). Social network and political participation: The role of social interaction in explaining political participation. Political Research Quarterly, 56(4), 449-464.

McLeod, J. M., \& McDonald, D. G. (1985). Beyond simple exposure: Media orientations and their impact on political process. Communication Research, 12, 3-34.

Mergel, Ines. (2012) The public manager 2.0: Preparing the social media generation for a networked workplace. Journal of Public Affairs Education, 18(3), 467-492. Retrieved from http://www.jstor.org/stable/23272651

Mutz, Diana C. (2002). The consequences of cross cutting networks for political participation. American Journal of Political Science, 4(4), 838-855.

Palfrey, Thomas R., \& Poole, Keith T. (1987). The relationship between information, ideology, and voting behavior. American Journal of Political Science, 31(3), 511-530.
Patterson, Thomas E., \& McClure, Robert D. (1976). The unseeing eye: The myth of television power in national elections. New York: G. P. Putnam's Sons.

Potter, W. James. (2012). Media effects. New York: Sage Publication, Inc.

Prior, Markus. (2005, Jul.). News vs. entertainment: How increasing media choice widens gaps in political knowledge and turnout. American Journal of Political Science, 49(3), 577-592. Retrieved from http://www.jstor.org/stable/ 3647733

Rheingold, Howard. (2002). Smart mobs: The next social revolution. Cambridge, MA: Perseus.

Sundar, S. S., Hesser, K. M., Kalyanaraman, S., \& Brown J. (1998, July). The effect of website interactivity on political persuasion. Paper presented at the $21^{\text {st }}$ General Assembly \& Scientific Conference of the International Association for Media and Communication Research, Glasgow, UK.

Susilo, Nina. (2016, April 5). Pemilih Muda dan Budaya Pop. Kompas, pp. 5. Politik dan Hukum

Tolbert, Caroline, \& McNeal, Ramona. (2003). Unraveling the effects of the internet on political participation. Political Research Quarterly, 56(2), 175-185.

Verba, Sidney, \& Nie, Norman H. (1972). Participation in America: Political democracy and social equality. New York: Harper and Row.

Verba, Sidney, Schlozman, Kay Lehman, \& Brady, Henry E. (1995). Voice and equality: Civic voluntarism in American Politics. Cambridge: Harvard University Press.

Ward, Janelle. (2007). Addressing young people online: The 2004 European Parliament election campaign and political youth websites. In Randolph Kluver, Nicholas W. Jankowski, Kirsten A. Foot \& Steven M. Schneider (Ed.), The internet and national elections: A comparative study of web campaigning (pp. 136-149). New York: Routledge.

Wattenberg, Martin P. (2008). Is voting for young people? With a postscript on citizen engagement. Singapore: Pearson Education, Inc.

Weaver, David H. (1996). What voters learn from media. The Annals of the American Academy of Political and Social Science, 546, 34-47. Retrieved from http://www.jstor.org/stable/ 1048168

Wood, Julia T. (2009). Communication in our lives ( $5^{\text {th }}$ ed.). Boston: Cengage Learning. 